\title{
SUSTRATOS CONVERSOS EN LA GREAGIÓN DE LÁZARO DE TORMES
}

El dictum de Plino el Joven, "no hay libro, por malo que sea, que no tenga alguna cosa buena", que el autor del Lazarillo de Tormes pone en boca de su personaje para su prólogo, cuando se aplica a la obra, quizás sea sólo una ironía más entre las muchísimas que contiene. Y aun casi se podría decir que ni siquiera su antífrasis - no hay libro, por bueno que sea, que no tenga alguna cosa mala- podría aplicársele. Lo cierto es que cuanto más se lee y relee la obra, más y más obvio resulta que hasta los más mínimos detalles - sean éstos léxicos, sintácticos, etc.- están cargados de sentido y cumplen una función bien determinada dentro de la estructura total, aunque muchas veces esto pase inadvertido.

Ya desde las primeras lineas creo que puede observarse. Comienza Lázaro su autobiografía diciendo: "Pues sepa V.M. ante todas cosas que a míllaman Lázaro de Tormes, hijo de Tomé Conzáles y de Antona Pérez. ." (I, pp. 1-2)1, confesión inicial con que el protagonista se nos presenta e identifica mediante ciertos pertinentes datos personales, pero ¿nos está diciendo todo con ellos? ¿todo, quiero decir, cuanto es necesario que sepamos para identificarlo plenamente como personaje?

Una lectura descuidada y ligera nos deja satisfechos y aceptamos sin más su nombre: Lázaro de Tormes; otra más atenta, sin embargo, revela cierta desasosegadora discordancia: la de que para presentar su nombre lo haga usando una construcción decididamente irregular y anómala como es ese "a mí llaman".

No se presenta el personaje diciendo "a mí me llaman" como hubiera sido más lógico, sino que, contra la regla sintáctica habitual, afirma "a mí llaman", omitiendo el obligado pronombre indirecto personal "me" normativo para esta clase de construcciones. A observar, además, que cuando de presentaciones personales se trata si en vez de "a mí me llaman" se dice simplemente "me llaman" la omisión de "a mí"

1 Cito por R. O. Jones, ed, La vida de Lazarillo de Tormes, Manchester University Press, Manchester, 1963. Todos los subrayados son míos. 
es perfectamente aceptable y la presentación, de darse el caso, sigue siendo correcta y usual, con lo que se resalta más contundentemente la omisión del "me". Hay que preguntarse por la ausencia de ese "me", siendo como es normalmente necesario para determinar a la persona desde el propio sujeto, y asimismo cómo ha de explicarse esa específica estructura sintáctica.

La primera posible solución a esta anomalía es que se trate, sin más, de un uso sintáctico general de la época, pero basta repasar el estudio de Keniston sobre la sintaxis de ese siglo para obtener una respuesta negativa ${ }^{2}$; aun para muchos años antes; yendo a los textos, tenemos $\mathrm{el}$ testimonio de Fernando del Pulgar que, en un ejemplo excelente por recoger a la vez los dos usos en una sola frase, en su Crónica de los Reyes Catolicos, hablando de la muerte de Vázquez de Arce, dice: "Murieron en aquella pelea dos caualleros principales; oll vno se llamaba. . Mar. tín Vázquez de Arce, e el otro llamauan Juan de Bustamante"s.

De mucho más peso, y definitivo para el caso, es lo que se lee en el mismo Lazarillo; al narrar su nacimiento dice Lázaro "con verdad me puedo decir nacido en el rio ${ }^{27}$, con uso de un indirecto "me" que es aún más de destacar por lo superfluo, ya que pudiendo muy bien haber dicho "con verdad puedo decir que nací en el río" o "con verdad puedo decir haber nacido en el río" sin violencia sintáctica alguna, no lo hace; con ello todo lo innecesario del "me" realza lo obligado del mismo en la confesión inicial. Y a mayor abundancia, el autor reitera más adelante el uso rcgular de csa construcción; al mencionar Lázaro a su padrastro informa: "Quiso nuestra fortuna que la conversación del Zaide, que assí se llamaba. . ." (1, pp. 44-45), empleando tanto el correspondiente pronombre oblicuo personal como la forma verbal "llamaba", en singular, que concuerda con el que es llamado y no con los que así le llaman.

Ejemplo final de que esa particular omisión del "me" venía a resultar suficientemente inusitada aun para los lectores del xvi es el Lazarillo casiigado (1573) de López de Velasco, en donde se recoge la significativa variante "a mí me llaman" adoptada por ese censor". Algo se esconde, pues, tanto tras la omisión como tras la aviesa intención de quien la usó.

Podría ocurrir también, claro, que fuese un simple descuido o error de impresión, pero el que en las tres ediciones de 1554 aparezca invariablemente esa omisión nos asegura de que no es ése el caso, y que no haya relación directa entre ninguna de las tres - como Caso González nos afirma en su edición crítica ${ }^{5}$ lo confirma.

2 Hayward Keniston, The syntax of Castilian prose: Sixteentib century, Chicago University Press, Chicago, 1937.

3 Hernando del Pulgar, Crónica de los Reyes Católicos, ed. J. Mata Carriazo, Espasa-Calpe, Madrid, 1946, t. 2, p. 238.

4 José Caso González, ed., La vida de Lazarillo de Tormes, Madrid, 1967 (anejo 17 del $B R A E$, p. 63, n. 2).

5 Ibid., p. 14. 
Así pues, no tratándose, ni de error ni de característica sintáctica del momento, queda abierta la posibilidad de que esa omisión sea producto de un uso estilístico tradicional que el autor recoge a imitación de otros modelos.

Así lo supone Lázaro Carreter cuando, comentando esa peculiar forma de presentación, señala que "El Abencerraje empieza igual: 'A mí llaman Abindarráez el moço. . ." y en nota 18 comenta: "Obsérvese la misma fórmula, a mí. llaman, en el Lazarillo", si bien no se detiene más en la particular omisión del "me", ni se pregunta el porqué de la misma ${ }^{6}$. Sigue el crítico señalando que el prototipo de esa presentación genérica es, notoriamente, el Amadís, y con todo acierto lo hace, pero habrá que añadir aquí algo que no destaca, id est, que también ese libro de caballerías parece ser prototipo para la omisión del "me", ya que cuando Amadís, justo al comenzar su peripecia de caballero andante, se ve obligado a declarar su identidad, dirá: "A mí llaman el Doncel del Mar"?. Que el Lazarillo imita paródicamente al Amadís ya lo ha visto la crítica suficientemente para ciertos aspectos ${ }^{8}$, y por lo mismo se puede suponer que la omisión pronominal es una ocasión más que el autor emplea para remedar ese género literario ridiculizándolo; sospecho, no obstante, que aun aceptado ese propósito, la intención del autor va bastante más allá.

El Amadís que dice "A mí llaman el Doncel del Mar” es el Amadís al principio de su carrera caballeresca; no habiendo llevado a cabo todavía sus portentosos hechos y hazañas, no tendrá derecho aún a presentarse como tal Amadís y habrá de conformarse, por tanto, con ese apodo que le han impuesto y por el que le conocen los demás; la omisión del "me" es así, para él, el reflejo de la ausencia de la personalidad que aún no ha llegado a conquistar; solamente cuando haya realizado esos hechos y esas hazañas podrá detentar con justicia su verdadero nombre y al reivindicarlo mediante su fuerza y valor se podrá dar la posibilidad de un hipotético "a mí me llaman Amadís" o, mejor, "yo me llamo Amadís" ante todos los demás; habiendo cumplido el proyecto vital para el que estaba destinado y conquistada plenamente su personalidad, podrá añadir el "me" que la representa, pero sobre todo podrá ya incorporarse con esc su nombre, Amadís, al linaje de los Gaula del que había surgido.

No ocurre, sin embargo, lo mismo con Lázaro; por el contrario y a diferencia de Amadís, será sólo al final de toda su peripecia vital — hay que recordar aquí la decisiva distinción entre el Lázaro actor que vive

6 Fernando Lázaro Carreter, "Lazarillo de Tormes" y la picaresca, Ariel, Barcelona, 1972, p. 72. El subrayado es del autor.

7 Garci Rodríguez de Montalvo, Amadís de Gaula, ed. E.B. Place, C.S.I.C., Madrid, 1959, t. 1, vi, líneas 300-303.

8 M. J. Asensio, "Más sobre el Lazarillo de Tormes', HR, 28 (1960), p. 248; A. Del Monte, Itinerario de la novela picaresca española, trad. E. Sordo, Lumen, Barcelona, 1971, p. 41; F. Lázaro Carreter, op. cit., pp. 72-74. 
la peripecia y el Lázaro narrador que posteriormente la cuenta- cuando nos diga: "A mí llaman", y omitiendo el "me" ya al final de esa carrera que de él conocemos nos está indicando que algo se ha invertido en su proceso vital cuando se compara con el de Amadís.

En efecto, se ha dado un quiasmo que ha de traducirse del siguiente modo: la hipotética presencia del "me" para Amadís es reflejo, como ya he señalado, de que mediante sus hechos se ha despojado de su sobrenombre y ha conquistado merecidamente su nombre propio, y que al hacerlo ha regresado a su linaje insertándose definitivamente en él; la ausencia real del "me" para Lázaro refleja, exactamente, lo contrario: que mediante y a causa de sus "fortunas y adversidades" se ha visto despojado de su verdadero, original nombre, ha adquirido un sobrenombre y, consecuentemente, se ha desgajado de su esti-pe desarraigándose para siempre de ella. Y eso parece desprenderse y aún verse confirmado por su inicial confesión a la que he de volver: ". . .que a mí llaman Lázaro de Tormes, hijo de Tomé Gonzáles y de Antona Pérez. . . Mi nacimiento fue dentro del río Tormes, por la cual causa tomé el sobrenombre. . " Hubiera sido mucho más sencillo para este mozo empezar su confesión diciendo simplemente "yo me llamo Lázaro Gonzáles Pérez, hijo de Tomé y Antona”, y el no hacerlo parece ser prueba de que alguna otra cosa quiere decirnos más o menos solapada y encubiertamente.

Resulta sobremanera curioso comprobar que de todos los personajes que en mayor o menor grado, de un modo u otro, han influido en su vida solamente sus padres aparecen no sólo con nombres sino, incluso, con apellidos, y aún tanto o más curioso que en ese proceso educativo en que consistirá su vida sean estos padres precisamente quienes, de hecho, menos peso tienen en el proceso; toda comparación con cualquiera de sus amos en esa línea es en perjuicio de los padres en cuanto a su formación se refiere y, no obstante, ninguno de los amos se ve honrado ni siquiera con un nombre. Sólo otro personaje, como sabemos, posee nombre propio entre todos ellos: el negro Zaide, su padrastro, pero a éste tampoco se le dotará de apellido y el solo nombre le habrá de bastar. Sus padres, que le han procreado físicamente, tendrán nombre y apellido; su padre putativo - de algún modo hay que calificarloúnicamente llegará a gozar de nombre. Finalmente, nos encontramos con que todos esos amos que nada han aportado a la filiación genética ni a la formación física del mozo, pero sí, y prácticamente todo, a su formación psicológica, ni siquiera nombres podrán ostentar. Considerando ahora el impacto en su formación psicológica - prácticamente nulo para sus padres, atenuadísimo para Zaide y definitivo para los amos-, se concluye que a mayor influencia formativa menos nominación corresponde o, dicho de otro modo, que esa inicial relación filial, genealógica, que se manifiesta por el vínculo de los apellidos y en él se fundamenta, disminuye progresivamente a medida que avanza su formación personal vital. 
La renuncia a ese lazo de relación filial aparece patentemente reflejada en la madre cuando al despedirlo, tras darle su bendición, le dice: "Hijo, ya sé que no te veré más" (I, 82) poniéndolo, acto seguido, en manos del ciego a quien corresponderá actuar de ahí en adelante en funciones de padre vicario, como él mismo reconoce cuando promete recibirle "no por mozo sino por hijo" (I, p. 76); sin embargo, se puede conoprobar perfectamente que a pesar de su promesa el ciego en ningún momento de su relación con Lázaro usa la expresión " "hijo", con lo fácil que hubiera resultado intercalarla alguna vez, detalle que refuerza muy sutilmente la pérdida de filiación genética, como ya he hecho ver con más pormenores en un trabajo anterior ${ }^{9}$.

También deben entrar en juego aquílos sucessvo alumbramientos de que ss sujeto el personaje: desde primero con el ciego ...." siendo cicgo me alumbro" (1, p. 107)- hasta el uitino -.." "quiso Dios alumbrarme" (VII, pp. 8-9) (alumbrar ha de entenderse además en una de sus acepciones como dar a luz)--, esos alumbramientos son progresivos re-nacimientos simbólicos, como ya ha visto Gilman ${ }^{10}$ y yo también he analizado en el trabajo ya citado; re-nacimientos que van sustituyendo al inicial nacimiento físico y alejándolo, así, de su primigenio linaje hasta virtualmente conseguir que éste desaparezca.

Por otra parte, la deliberada y explícita inclusión de los apellidos de los padres, que bien pudieran haber sido omitidos como lo son para los demás personajes, y aunque sólo fuera porque después de tan larga separación sería aceptable que Lázaro los hubiera olvidado, alcanza aquí un singular relieve; cl autor no ornitirá esos apellidos paternos y bien se cuida de hacerlo porque, en mi opinión, destacándolos para los paIres y no usándolos para el hijo, presenta mejor la conciencia de pérdida de filiación de éste; y aún se puede ir más lejos y afirmar que la función principal, si no única, de la inserción de esos apellidos es, paradójicamente, asegurarnos de su inexistencia posterior, y que están ahí para ser negados, es decir, para convencer al lector de una vez por todas que ya no podrán atribuírsele a Lázaro porque ya no le pertenecen. La ausencia del "me" viene a ser algo así como eco reverberante de esa negación y falta de pertenencia, en cuanto que es exponente de una paralela pérdida de la personalidad original que el personaje pudo tener. Pero ese "me", sin embargo, no se habrá perdido, y bien que tendrá lugar y función dentro de la confesión de identidad de Lázaro.

Si dice "a mí llaman", también dice, no se olvide, "con verdad me puedo decir nacido en el río". El sustrato castizo personal que con la inicial omisión del "me" se negaba, reaparecerá con su inclusión posterior incorporándose al de su otro nacimiento, pero la casta que se recupera aquí ya es distinta, es la dada por ese último linaje fluvial: “ $\mathrm{Mi}$ nacimiento fue dentro del río Tormes, por la cual causa tomé el sobre-

9 M. Ferrer-Chivite, "Lázaro de Tormes, personaje anónimo", $C H(6), 235-238$.

10 S. GILMAn, "The death of Lazarillo de Tormes", PMLA, 81 (1966), 149-166. 
nombre"; y será su sobrenombre - "de Tormes" - ya para siempre.

Que yo sepa, ha sido Bataillon el único a quien le ha llamado la atención ese "dentro del río Tormes", "y no en sus orillas", como precisa, pero para él esa expresión "es la intencionada precisión”, “indicio de que un Lazarillo de Tormes preexistente fue conocido. . . por nuestro autor. . ."11 Intencionada precisión sí que la hay, sin duda, pero con otra función, a mi juicio; no creo que la imagen tan fuertemente locativa de "dentro del río" sea indicio de lo que señaló el llorado maestro; como en sentido recto y propio es imposible para nadie nacer dentro de un río, a lo que el autor apunta y destaca eficazmente con ese dentro es al simbólico ámbito uterino de las aguas del Tormes que habrán de substituir para siempre en Lázaro el físico de las aguas amnióticas de su madre Antona. Y asi es como ha de entenderse, creo, que quien debiera haber comenzado su confesión diciendo "Yo me llamo Lázaro Gonzáles Pérez" la empiece afirmando "a mí llaman Lázaro de Tormes".

Pero aún es más provocativa esa confesión cuando se considera otro rasgo de ella, uno muy curioso que permitirá redondear la personalidad - sea cual sea- que este destrón acabará detentando. Aunque hubiera dicho "a mí me llaman" seguiría persistiendo la sugestiva particularidad que se esconde tras el empleo de la forma verbal en tercera persona plural "llaman".

Si cualquiera se presenta diciendo que le llaman Fulano o Zutano, la inmediata reacción de su interlocutor será, a no dudarlo, preguntar le acto seguido cuál es su verdadero nombre, el que se oculta tras el que le ha dado, convencido de que ése no es nada más que el apodo o mote que le adjudican los demás.

Rasgo éste de la confesión que confirma lo que ya se podía sospechar de la omisión pronominal; es decir, que junto a la conciencia de pérdida de filiación se da concomitantemente la convicción, la certeza de que son los otros, los demás -el grupo social en general- los que le han impuesto el sobrenombre que ahora lleva, y que el haberlo hecho le ha concedido esa personalidad, ese nuevo linaje con que finalmente se presenta. De su padrastro dirá: “. . . Zaide, que assí se llamaba”; ese "se" indica su sustrato personal para el personaje, así como ese "llamaba" en singular delata su identidad con el nombre y con ello el derecho al usufructo del mismo, con el que plenamente se identifica; no es lo importante para él cómo le puedan llamar los otros, sino cómo él lo hace consigo mismo, consciente de que ese Zaide representa y aún más, mantiene, precisamente, su identidad; por el contrario, el "a mí llaman" de Lázaro de Tormes es el persistente eco en la conciencia del mozo de la ausencia de una identificación con el nombre adjudicado; perdido su original linaje, parece ser asimismo muy consciente de haber

11 Marcel Batalllon, Novedad y fecundidad del Lazarillo de Tormes, trad. L. Cortés Vázquez, Anaya, Salamanca, 1968, p. 29. 
perdido con él el usufructo de un nombre con el que pudiera identificarse; el que tiene, el que los otros usan para dirigirse a él parece que le sea simplemente eso, un signo referencial que los otros le han impuesto y que él ha de aceptar por necesidad social aun a sabiendas de que ese referente relacional - a diferencia de Zaide - no es su nombre verdadero, no le corresponde con exacto rigor.

Se aducirá, y con razón, que no puede afirmarse en buena ley que carezca de nombre, ya que repetidas veces se oye en boca de sus amos, y aun en la suya, pero no se trata aquí de la existencia o no del nombre, sino de hasta qué punto curnple para él una función plenamente identificativa respecto a sí mismo, hasta qué extremo él mismo se reconoce totalmente en el nombre.

Ginco veres usará é ciego "Lazaro" (1, pp. 89, 216, 275, 361 y 384) y una "Lazarillo" (1, p. 310), ya sea para llamarle la atención o para recriminarlo; dos veces "Lázaro" (II, pp. 180 y 378) el clérigo de Maqueda; cinco "Lázaro" (III, pp. 139, 186, 293, 388 y 438) el escudero, para acabar, por fin, con un último "Lázaro de Tormes" en boca del Arcipreste de San Salvador (VII, p. 44); también Lázaro empleará el nombre para referirse a sí mismo cinco veces, curiosamente las mismas del ciego y el escudero - si hay una posible escondida razón para esa simetría numérica no puedo detenerme aquí en considerarlay siguiendo la pauta anterior respecto a sus amos en los primeros tratados, lo hará a secas para acabar con el último - detalle mínimo pero digno de consideración-, usando el compuesto Lázaro de Tormes al igual que el Arcipreste. Tanto amos como criado usarán ese nombre Lázaro, que habrá de acabar en Lázaro de Tormes, como ya he hecho notar, y más adelante se verá el porqué, pero si para los primeros no es dudoso que ese uso cumple una función identificativa, que se da una fusión obvia entre referente y referido, es más discutible que éste sea el caso para el segundo.

La primera vez que se menciona a sí mismo es con motivo del jarrazo que el ciego le propina al descubrir que le está bebiendo el vino mediante la añagaza de la cera derretida, como sabemos, y ahí nos cuenta que

alzando con dos manos aquei dulce y amargo jarro le dejó caer sobre mi boca. . . de manera que el pobre Lázaro que de nada de esto se guardaba, antes. . . estaba descuidado y gozoso, verdaderamente me pareció que el cielo. . me había caído encima (I, pp. 202-208).

Esta sorprendente silepsis pronominal no puede pasar inadvertida a ningún lector mínimamente atento; a nadie se le puede pasar por alto la flagrante discordancia entre esa primera persona que narra la anécdota y aparece justamente representada por esos "mi", "me" y "me" y el objetivado "pobre Lázaro" en tercera que se ve recalcado en su ob- 
jetivación por el "se", sabiendo como sabe el lector que se trata del mismo sujeto.

Hay, sí, un quebrantamiento de lo gramatical, pero en rigor no lo hay de lo psicológico; ocurre simplemente que el narrador tiene clara conciencia de que entre su yo íntimo, personal, y su nombre hay un evidente vacío, un distanciamiento que le permite decir "de manera que el pobre Lázaro. . ." cuando debiera haber dicho con toda lógica "de manera que yo, pobre Lázaro. . ." Para ese narrador, obviamente, una cosa es el yo y otra muy diferente el nombre Lázaro aplicado a ese yo y que ha de servirle de identificación, o, si se quiere, que entre ellos no hay la consustancial y necesaria compenetración que esa relación supone y exige.

Esa peculiar discordancia habrá de repetirse; cuando el mozo reflexiona sobre su menesterosa condición con el clérigo de Maqueda, dice: "Cion esto no me osaba menear, porque tenía por fe que todos los grados había de hallar más ruines; y a abajar otro punto, no sonara Lázaro ni se oyera en el mundo" (II, pp. 100-102).

Reincidiendo en esta línea, se comprueba nuevamente que frente a un posible y más lógico "ni sonara yo ni se oyera de mí en el mundo", más en concordancia con el "me" inicial, dice lo opuesto. Parece, pues, que el nombre de Lázaro le resulta bastante ajeno y distante a quien lo cita y oficialmente lo detenta. Más adelante, quejándose de la vanagloria e hipocresía de su amo el escudero, reflexionará: “ ‘. . .quién pensara que aquel gentil hombre se pasó ayer todo el día sin comer, con aquel mendrugo de pan que su criado Lázaro trujo un día y una noche en el arca de su seno. . .?" (III, pp. 201-204).

Poco después lo presentará “. . .yéndose el pecador. . . con aquel contento y paso contado a papar aire por las calles, teniendo en el pobre Lázaro una cabeza de lobo" (III, pp. 323-325).

Lo destacable aquí, y conocida ya la reiteración del procedimiento, es que acto seguido resumirá su situación con un "Contemplaba yo muchas veces mi desastre" en abierta oposición al "pobre Lázaro" en tercera persona; ni dirá siquiera "teniendo en mí una cabeza de lobo", como tampoco en el caso anterior habrá dicho "aquel mendrugo de pan que yo truje". Persistiendo en esta particularidad aparece el último ejemplo a citar; refiriéndose a su éxito como pregonero, nos asegura " . . que en toda la ciudad el que ha de echar vino a vender o algo, si Lázaro de Tormes no entiende en ello, hacen cuenta de no sacar provecho" (VII, pp. 21-23).

Repitiendo esa omisión del yo cuando tan a mano vendría, no diciendo "si yo no entiendo en ello" en vez de "si Lázaro de Tormes no entiende en ello", es evidente el énfasis en el hecho de ser un cierto Lázaro de Tormes quien les pregona esos vinos y esos algos a todos los demás, esos demás para quienes el pregonero ha cristalizado en Lázaro de Tormes, pero tan evidente o más es que ese pregonero no está compenetrado en absoluto con el nombre en el cual subyace su personali- 
dad. La posibilidad de que esa compenetración exista se descarta plenamente al verificarse, sin lugar a dudas, el elocuente dato de que a lo largo de toda su autobiografía el mozo menciona el nombre como referente a sí mismo las cinco veces citadas - y nada más que ésasy en todas ellas, sin excepción alguna, aparece siempre como referido a una tercera persona, y se refuerza y confirma indirectamente al comprobar que en ningún caso Lázaro usa ese nombre inmediatamente apuesto al pronombre "yo", cuando pudiera haberlo hecho, y baste aquí un ejemplo por todos; en un inciso respecto al escudero dice: "Y yo que le servía de pelillo" (II, pp. 166-167); muy bien pudiera haber dicho, y aun la ocasión parecía reclamarlo, "Y yo, Lázaro, que le servía de pelillo", pero no lo hará, como tampoco en ninguna de todas las otras oportunidades posibles.

Suponer que esas lanativas y reiteradas particularidades sean producto de mera coincidencia o fortuito azar sería concederles un excesivo papel que difícilmente se puede aceptar en una obra tan diestramente construida y elaborada como la que nos ocupa. Hay que admitir, sencillamente, que el autor se ha servido de esos recursos para transmitirnos sagazmente lo que se oculta tras el carácter de su personaje y proporcionarnos una especial clave bajo la cual se delinean los rasgos que determinan su intrigante fisonomía.

A esos recursos hay que añadir uno último, que deliberadamente he postergado, siquiera por aquello de ser también el último que determina el destino final del personaje. Ya he hecho notar antes que, en la trayectoria nominal ha sido siempre Lázaro, y solamente Lázaro, el nombre usado por sus amos así como por él mismo cuando a sí se refería, y que solamente al final de su peripecia vital es cuando se da un cambio. Al defender el arcipreste el ménage à trois en que andan envueltos, se dirige a él diciéndole: "Lázaro de Tormes, quien ha de mirar a dichos de malas lenguas, nunca medrará" (VII, pp. 44-45), empleando por primera vez el nombre completo; así ocurre también con él mismo, ya que la última vez que de sí habla - y solamente en ésa - nos dará nombre y sobrenombre para presentarnos a ese pregonero que él es, como Lázaro de Tormes.

Tampoco es coincidencia ni producto de azar que así suceda; mediante ese último y deliberado recurso, lo que el autor está poniendo de relieve es que sólo cuando su personaje haya acabado su proceso de adaptación a la sociedad y haya sido cumplidamente moldeado por la misma para, en su opinión, ser digno de ella con todos los honores, solamente entonces el grupo social condescenderá con él y completará su labor onomástica, considerando ya llegada la hora de otorgarle una nueva estirpe $y$, con ella, su nuevo sobrenombre ${ }^{12}$. Y de que el mozo ha

12 E⿺ aspecto personal de ese proceso de adaptación de Lázaro a la sociedad lo he estudiado en otro trabajo; cf. M. FERRER-CHrviTe, "Proceso psíquico de interiorización dialéctica de Lázaro", en J.L. Alonso Hernández, ed., Teorías semiológicas aplicadas a tex- 
aprendido bien la lección y ha sacado sobresaliente en ese cursus honoris social, integrándose, así, de lleno en el grupo, es excelente prueba - nos está diciendo el autor-- el que haya aceptado irrecusablemente esa máscara de pregonero llamado Lázaro de Tormes y que airee ya abiertamente ese sobrenombre impuesto por los otros.

Con esos recursos - y todo lo que tras ellos se esconde- el autor está haciendo rabiosamente viva la fisonomía de esa peregrina criatura que ha surgido de sus entrañas y desvelos, esa criatura que ha perdido su casta y se ve aislada en su soledad - recuérdese que inmediatamente después de despedirse de su madre, y de la pertinente calabazada, su primera experiencia psíquica es la de la soledad reflejada en ese " solo soy y pensar cómo me sepa valer" (I, p. 100)- y que, arrojada con esa patética carga dentro de la sociedad, ve como ésta, despreciando su original estirpe - los González y Pérez de sus padres--, se limirará a llamarle Lázaro - de algún modo ha de hacerlo cuando más peyorativamente no le llama "mozo" - hasta que, habiéndole indoctrinado apropiadamente y como premio a su éxito en el sometimiento, le concederá finalmente un nuevo linaje: el de Tormes; pero Lázaro mantendrá viva su conciencia del proceso sufrido y su venganza consistirá como muy primera cosa y ante todo - no se olvide que inicia su confesión diciendo "Pues sepa V.M. ante todas cosas - en poder echarle en cara a esa Vuesa Merced y con él a todo el grupo social que representa, ese acusador "A mí llaman Lázaro de Tormes", abrumadora síntesis del producto social que ha llegado a ser o, mejor, que le han obligado a ser.

El patético dramatismo y la densa humanidad que inundan a Lázaro son demasiado consistentes y de peso como para ser mero producto de una exhibición virtuosista o un recreo de diletante que se entretiene escribiendo facecias. De haber sido así no tendría la fibra vital que le recorre ni la compacta psicología que le caracteriza, y el autor hubiera producido otro inane e insustancial Palmerín o Cirongilio, otro falso Abindarráez u otra artificiosa Diana de acuerdo con los modos literarios de su tiempo.

Pero Lázaro, bien es sabido, nada tiene en común con esos otros; contra ellos se alza y contra sus exorbitantes proezas, sus arrogantes honras y prosapias y sus delicadas ñonerías arremete; pero es que estos Palmerines, estos Abindarráez y estas Dianas - y se me perdonará recordarlo- viven absolutamente fuera del tiempo y del espacio de sus lectores; Lázaro, no; Lázaro vive en su Salamanca y aún mucho más en su Toledo; Lázaro vive en el remado de Carlos V. Esos otros han podido tener su origen, motivación y vigencia en otros tiempos, en situaciones sociales distintas que los validaban, pero todo ello, por pretérito e inexistente, no sirve ya como sustento firme para la creación de figuras vivas, atrayentes, sino sólo para repetir desangelados y monótonos estereotipos.

tos españoles. Actas del primer Symposium Internacional del Departamento de Español de la Universidad de Groningen (Groningen, 1980), 135-159. 
Lázaro, en cambio, nacerá con y en el tiempo de sus lectores y — salvadas las distancias - suya será la misma coyuntura social e histórica en que surge y se mueve, que lo modela y justifica. Como creaciones literarias los otros personajes y éste serán contemporáneos cronológicamente; como creaciones insertas y derivadas de un específico marco sociohistórico, por supuesto que no, y no es necesario subrayarlo demasiado. Comparado con esos otros, es obvia la radical condición de personaje nuevo que representa Lázaro; y no hablo aquí, claro está, de la novedad en la historia de la literatura, ya demasiado conocida, sino de otra que no se ha visto tan a menudo: la relacionada con el marco sociohistórico que posibilitó su aparición o, en otras palabras, el hecho de que Lázaro tuvo que ser una creación nueva porque nuevos eran los tiempos que lo potenciaron y con los cuales un nuevo hombre, sociohistóricamente hablando, se había producido.

$\mathrm{El}$ autor - y no descubro nada que no se sepa ya- hubo de ser muy consciente del giro que la coyuntura histórica había dado y experimentando y aun sufriendo las consecuencias de ese cambio, los efectos que se habían producido en su entorno y en él mismo - que hombre de su época era y abierto, a no dudarlo, a sus novedades-, ellos le impulsaron al cincelamiento de ese protagonista que tanto tiene de síntesis y epítome de esos cambios; y así le nació una figura viva y acongojante porque vivas y acongojantes eran muchas de las ansias y tensiones suyas y de sus contemporáneos, de sus motivaciones, pasiones y reacciones, en suma, de esa constelación de sentimientos e ideologías que constituyeron la problemática total de esa "edad conflictiva" —en acertada denominación de Américo Castro- de la España de sus momentos ${ }^{13}$.

De esa problemática general de la España de la primera mitad del xvi no cabe duda ya, a estas alturas de la historiografía actual, que fue causa - si no la única, por supuesto, no la menor tampoco- la conversión forzada al cristianismo de una enorme masa de hispánicos, provo-

13 R. ReXACH ("El hombre nuevo en la novela picaresca española", CuH, 92, 1973, 367-377) dice: "En el Lazarillo. . . el hombre nuevo está ahí sin más, como un producto natural y espontáneo de las nuevas condiciones sociales. . ." (p. 368), y para DEL MONTE el autor del Lazarillo tuvo que participar de "la conciencia de una desviación de España de su propio destino" y advertir "que la política imperialista de Carlos V traicionaba las aspiraciones de su pueblo. . ." (op. cit., p. 40), motivándole, así, para su creación. También últimamente Francisco Carrillo (Semiolingüística de la novela picaresca, Cátedra, Madrid, 1982) dice: "La estructura profunda de la picaresca es descubierta por el contexto situacional que presenta en primer plano el problema social, religioso y moral de los cristianos nuevos" (p. 154) y, más en concreto, "la conciencia del autor del Lazanillo es parte de la conciencia intelectual de su tiempo" (p. 159). Para lo mucho y trágico que se ocultaba tras esos generales condicionamientos sociales, religiosos e ideológicos véanse el excelente trabajo de J. I. Gutiérrez Nieto, "La discriminación de los conversos y la tibetización de Castilla por Felipe II', RUCo, 2 (1973), núm. 87, 99-129; BARTOlomé Bennassar, L'Inquisition espagnole: xve $x i x^{\ell}$ siècle, Hachette, Paris, 1979 (caps. 4 y 5); y, por supuesto, Américo Castro, De la edad conflictiva, Taurus, Madrid, 1961, y otros conocidos trabajos suyos. 
cada, ya se sabe, por el edicto de expulsión del 31 de marzo de 1492.

También se sabe que antes se habían dado otras conversiones más o menos masivas, ya desde el pogrom de 1391, pero, en todo caso, parciales y sin afectar a los miles de judíos que decidieron seguir viviendo dentro de su respectiva ley y casta manteniendo sus modos de vivir, sus costumbres, sus ritos y no menos sus nombres de familia. Pero todo cambió con la decisión de 1492; o conversión o expulsión sin apelación posible, y de sobra es conocido lo que a todo ello se siguió.

$\mathrm{Y}$ de entre las bastantes cosas que siguieron no fue la de menos importancia la implícita necesidad en que se vieron miles de esos judíos al aceptar el bautismo y, consecuentemente, a adoptar nombres y apellidos de los hispano-cristianos. El impacto de esa medida y sus consecuencias se reflejan de modo particular en algunos documentos de la época

El personaje noble Godoy del Diálogo de los pajes de palacio de Diego de Hermosilla, redactado allá por la década de 1540, comenta los efectos de tales conversión y bautismo con su interlocutor Lorca, de adecuado y oportuno origen converso:

GODOY. - . . vna mala costumbre que con vuena fin e intención se introdució en Castilla en gran perjuicio aunque no se echa de uer, en la nobleça della. .

LORCA. - ¿Qué costumbre?

GODOY. - . . que cuando los Reyes Católicos . . .desterraron a los judíos de Castilla y ganaron el reino de Granada a los moros. . . los más que. . se convertían a nuestra santa fe católica, tomauan por padrinos de pila a los hidalgos y caualleros más prençipales que avía en los lugares donde se vautiçaban; y estos les permitían por honrallos que tomassen sus apellidos. Y venidos en su poder, hallándose tan vien con ello que los publican y señalan por suios, mayormente donde no los conoçen. . ${ }^{14}$

Esa "mala costumbre" introducida en Castilla con motivo de las conversiones, esa alegría, presunción y honra que los nuevos apellidos proporcionan, al parecer, a los recientes cristianos se verán ratificadas y criticadas aún más sañudamente en uno de los más vitriólicos ataques contra los cristianos ruevos del xvı que yo conozca, el Diálogo entre Laín Calvo y Nuño Rasura, datado en 1570 . Su anónimo autor reconstruye una imaginaria conversación entre los dos personajes cidianos, que ven adulterada y pervertida su ciudad de Burgos por la turbamulta de cristianos nuevos, y se deshace en improperios y diatribas contra ellos, facilitándonos, bajo ropaje literario, una excelente información histórica sobre sus hábitos y características.

14 Diego de Hermosilla, Diálogo de los pajes de palacio, ed. D. Mackenzie, Univ. Microfilm Int., Ann Arbor, 1980, p. 60; acerca de este Diálogo es muy sugestivo lo que Francisco MÁrQUez Villanueva dice: "este diálogo escrito al menos parcialmente a principios de la década de 1540 , guarda notable afinidad ideológica con el Lazarillo". Cf. Espiritualidad y literatura en el siglo xvi, Alfaguara, Madrid, 1968, p. 122, nota 75. 
Entre otros no más halagüeños comentarios dirá Laín:

. . por encubrir su suçia sangre tienen autoridad de mudarse los nombres como Pontífices. . . que de esto de linaxes précianse mui mucho. . . Y el mal es que como los bautiçaban de edad de setenta y ochenta años, tomaban los apellidos de los padrinos, y ansí agora vn judío renouero de estos dice que es del linage y casa de Herrera, el otro de Benauides, el otro de Arellano. . . siendo un marrano reçién conuertido. . .15

Para Diego de Hermosilla y más para ese anónimo autor es patente lo negativo de esa conversión, y más de lamentar parece ser, en particular, la honra que ha aportado ese nuevo apellidamiento a los cristianos nuevos. Pero ésa es la visión y la lastimada opinión de un grupo dominador que, habiendo impuesto nombres a sus antiguos enemigos de casta y fe, observa los opuestos efectos que han resultado de sus acciones e intenciones.

Esas lamentaciones, sin embargo, no parecen tener fundamento tan sólido cuando se considera la otra parte en litigio; la felicidad, la presunción y la honra que se suponían derivadas de esos cambios de nombre fueron más que discutibles para muchos de los individuos de la otra parte interesada, para los cuales parece que tales cambios no produjeran tan agradables resultados. $\mathrm{O}$, al menos, así se desprende de un documento del que extraigo las líneas que al caso vienen.

En el ms. 9175 de la BNM se recogen unas memorias de Sebastián de Horozco en las que, tras hacer relación de las reconciliaciones y autos de Toledo en el siglo XV, hablando de los correspondientes sambenitos, dice:

. . los sambenitos de todos estos quemados se. . pusieron colgados. . . en la sancta iglesia de Toledo. . . mas porque andando el tiempo. . . los dichos sambenitos estaban ya rotos y gastados y no se podían leer. . . fueron mandados renouar y poner en cada perrocha de esta cibdad donde los tales quemados o reconciliados eran perrochanos y en las iglesias de los lugares de donde eran naturales lo cual se fizo en el año de mil quinientos treinta y ocho. . . e yo lo vi lo qual pesó infinito a los confessos de Toledo descendientes de aquéllos e por esto todos o los más se han quitado y mudado los nombres antiguos que tenían de sus agüelos y antepasados que ya en esta cibdad no se hallaran quien de aquellos nombres y apellidos antiguos de confessos se llame así como Fagueìes, Guaypames, Gafayres, Sorges. . . Jaradas, Cotas. . . Hayetes. . Faros. . Pabones. . . Chapateles. . . Garbales. . .,

y una larga letanía de más nombres que comprende hasta treinta y nueve familias, y aun podemos suponer que algunos más se dejaría Horozco

15 BNM, ms. 3796, ff. 1-9; fue publicado por R. Foulché-Delbosc, "Diálogo entre Laín Calvo y Nuño Rasura”, RH, 10 (1903), 160-183, esp. p. 169. 
en el tintero por no hacer excesivamente prolija la lista ${ }^{16}$. Por supuesto, los efectos de esta sambenitada que "pesó infinito a los confessos de Toledo" no fueron exclusivos de esa ciudad; no es de extrañar que análogas reacciones se dieran por toda la península, como lo acredita el anterior noble Godoy que, siguiendo con esos cambios de apellido, explica:

. . lo hazen con cautela, porque se acaue y oluide el apellido de su casa; y con este ardid, aunque se miren todos los sanvenitos que hay en las iglesias de España, de los tornadiços no se hallara ya ninguno de los apellidos que en ellos están. . . ${ }^{17}$

Volvendo a Toledo - y a Toledo hay gue volver, que ao en vano ahí se centra la accion del Lazanllo-, hoy sabemos en concreto el resultado material en que se tradujo la reterida sambenitada. Lo que Horozco no dijo, Gómez-Menor lo ha expuesto informándonos de los cambios de apellidos que se dieron en esa ciudad en la primera mitad del XVı para familias judeo-conversas, y más específicamente para muchas de las que Horozco cita.

Por la información de Gómez-Menor nos enteramos de que

Los Sorges tomaron los apellidos Álvarez, Santa Cruz y De la Cruz; los Jaradas, el De la Fuente; los Havetes, el de Hernández de Móstoies; los Pabones, el de Ramírez; los Faros son los Sánchez de Segovia; los Chapateles son los Álvarez de Toledo y Zapata; Ios Garvales usaron el de García. . . los Cotas tomaron los apellidos Sánchez, Sandoval, los Fahuel, el de López. . . ${ }^{18}$

16 BNM, ns. 9175, r. 91 . Si Horozco dejó deliberadamente o no algunos en el tintero, no lo sabremos nunca, pero sí que algunos más había en la lista ya que dos aparecen tachados y otros están guillotinados corno resultado de la encuadernación. A. Martín Gamero (Historia de la ciudad de Toledo, sus claros varones y monumentos, Impr. de S. López Fando, Toledo, 1862, t. 2, pp. 1065-1066) copia la lista; lo hace también Francisco Cantera Burgos, Judaizantes del arzobispado de Toledo habilitados por la Inquisición en 1495 y 1497 (Univ. de Madrid, Madrid, 1969, pp. xxxii-xxxiii) y, comentando esa lista, añade: "Si se compara esta serie de apellidos con los más frecuentes en nuestro índice onomástico de los que figuran en las listas de 1495 y 1497, podrá comprobarse que algunos de aquéllos no aparecen en ellas, y otros se dan con escasez'.

17 Diego de Hermosilla, op. cit., p. 62.

$18 \mathrm{~J}$. C. Gómez-Menor, "La sociedad conversa toledana en la primera mitad del siglo XVI", Simposio Toledo Judaico (Toledo, 1973), t. 2, 51-63, esp. p. 62. De la necesidad del cambio de nombre como procedimiento de adaptación psicológica al medio algo dice B. Escandell Bonet, "Una lectura psico-social de los papeles del Santo Oficio: Inquisición y sociedad peruanas en el siglo xvi", en J. Pérez Villanueva, ed., La Inquisición española: nueva visión, nuevos horizontes, Siglo XXI, Madrid, 1980, 462-465. Nicolás LóPeZ MARTínez (Los judaizantes castellanos y la Inquisición en tiempos de Isabel la Católica, Luz y Vida, Burgos, 1954) cita “. . .la clandestinidad y habitual hipocresía que llenaba la vida de una masa ingente de falsos conversos, vida doble llevada hasta el extremo de usar nombres distintos según que con cristianos o judíos trataran. . ." (p. 211). ¿A cuántos de esos toledanos y otros repartidos por España podría suponérseles esta característica? En líneas siguientes algo comento en relación con este asunto. 
Desde la perspectiva de Hermosilla y el autor del Diálogo, y con ellos el grupo social que representaban, es muy probable que esos nuevos Álvarez, De la Fuente, Hernández de Móstoles, Ramírez, etc., pudieran sentirse felices y honrados con esa máscara de sus nuevos apellidos y hasta que presumieran de ellos ante los otros; desde el punto de vista y los sentimientos de los antiguos Sorges, Jaradas, Havetes, Pabones, etc., es tan probable o más que la realidad fuera muy otra si hacemos caso del pesar infinito que Horozco denuncia y que viene a resultar trágico puente entre los dos planos vitales en que esos cristianos nuevos toledanos hubieron de moverse y, por otra parte, justa medida del con-flicto psíquico en que se vieron obligados a debatirse.

Es obvio que para ellos no se trataba de la simple compulsión material de enjaretarse el nombre nuevo que la conversión y el bautizo suponían; de haber sido sólo un trámite legal, es de suponer que hubieran tomado el asunto a la ligera; quizás, incluso, con cierto regocijo, como - y valga el ejemplo aun a riesgo de que resulte pedestre- el que podían sentir al estrenar unas calzas o un jubón, digamos; el problema aparece -y sigo con el ejemplo por lo útil y gráfico que resulta-cuando esas calzas o ese jubón no le caen bien a uno, cuando uno se siente enormemente incómodo y desasosegado dentro de esas prendas; se agrava cuando a uno le han obligado, directa o indirectamente, a ponérselas y se agudiza hasta casi lo intolerable cuando el usuario tiene clara conciencia de que tales prendas no encajan en la categoría y prestigio que le corresponden, como sin duda debía ser el caso de esos toledanos que, se quisiera o no, debían seguir considerándose en lo hondo de sus entrañas como el pueblo elegido por encima de las otras castas. No es, pues, en la compulsión material donde se halla la raíz de la cuestión, sino en la psicológica que debieron sufrir viéndose obligados a llevar esos Álvarez, esos Santa Cruz, esos De la Fuente, etc., que se les presentaban como psicológicas camisas de fuerza de las que ni siquiera podían desprenderse sin riesgo de sus famas, fortunas y aun vidas.

Piénsese, además, que la necesidad de persistir y coexistir dentro de su grupo social exigía de ellos el ir revestidos día tras día con esos nombres que velis nolis les recordaban, por otro lado, cotidianamente al grupo que les había forzado a adoptarlos, grupo al que, por supuesto, nunca se hubieran asimilado sua sponte. Quizás no hubiera sido tan grave el problema de haber existido algún resquicio por el que manifestar su desagrado ante tal compulsión, pero, desgraciadamente, no fue éste el caso; la coyuntura histórico-social de aquellos momentos estaba trazada de tal modo que esos toledanos no sólo no podían airear su repulsa de los nuevos apellidos sino que, por el contrario, incluso se veían en la necesidad de aparentar su contento por haberlos adquirido y hasta de hacer ostentación de ellos como nos lo han hecho ver Hermosilla y el autor del Diálogo.

No se puede pretender, cierto es, que todos esos Sorges, Jaradas, Havetes, etc., persistieran en las prácticas secretas de los ritos y hábitos 
de sus antepasados dentro del seno familiar como tantos cripto-judíos se sabe que hicieron -y suficientes procesos conocemos que así lo confirman- pero sí, por lo menos, que siguieran siendo y sintiéndose Sorges, Jaradas, Havetes, etc., de puertas adentro; otra cosa bien distinta, por supuesto, tuvo que ser su actitud de puertas afuera, cuando salían a la vida pública y habían de rozarse y tratar necesariamente con quienes sabían de su anterior estirpe; cuando, enmascarados tras esos nuevos apellidos y forzados por las ineludibles presiones sociales, tenían que alardear de ellos a fin de intentar defensivamente aparecer como más cristianos viejos incluso que esos mismos cristianos viejos que en muchos casos hay que suponer estarían - consciente o inconscientemente- al acecho y con los que, bien a su pesar, se veían reducidos a coexistir, como he recordado antes.

Todo lo cual, agudizando las tensiones psíquicas, serviría de acicate para espolear más su aversión tanto al grupo social en que se movían como a los apellidos impuestos por éste, y de los que, sin mucha duda, se hubieran desprendido en la primera ocasión posible, como tantos de sus correligionarios hicieron en cuanto se hallaron lejos del alcance inquisitorial en Amsterdam, Ruán, Liorna o lugares análogos y bien conocidos.

Sé, por supuesto, que con el anterior panorama tan brevemente descrito no he descubierto ningún modo nuevo; sabido es que Caro Baroja, Castro, Netanyahu, Gilman, Domínguez Ortiz, Sicroff - entre otrosya lo han expuesto cada uno a su modo y muy suficientemente - en último término, todos ellos han sido mis mentores para estas reflexiones-, pero me ha sido necesario detenerme en él siquiera para recordar los conflictivos años que les tocó vivir - o "desvivir", como Castro quiere- a esos históricos toledanos y no menos, toledano o no, al autor del Lazarillo. Años en que un gran número de españoles se vieron despojados, si no de su tierra natal -en la que prefirieron permanecer por decisión propia - sí de sus estirpes y nombres, y esto, al contrario, por decisión ajena; años en que muchos de esos Sorges, Jaradas, Havetes, etc., quizás dijeron más de una vez en su fuero interno "A mí llaman Álvarez" o "A mí llaman De la Fuente", como habrá de hacerlo su proyección literaria, de acuerdo con mi interpretación.

Ciertos rasgos socio-históricos que actuaron sobre la psique y el carácter conversos pudieron servirle al autor del Lazarillo para elaborar las constantes intrínsecas - pérdida de linaje, nombre y personalidad originales y conciencia de haber sido impuestos unos nuevos por el grupo social- que fundamentan la estructura interna de su personaje y lo configuran como la entidad literaria que conocemos, según supongo. Si esto es válido para esa estructura interna, creo que también pueden verse proyectadas sensibilidad y mentalidad conversas en la presentación externa, en concreto en ciertas connotaciones adheridas al específico nombre elegido por el autor.

Nada hay que objetar a la general opinión sostenida por la crítica 
de que el autor se haya inspirado tanto en la tradición hagiográfica como en la popular, sea ésta folklórica o paremiológica, para su elección del nombre Lázaro, pero aceptadas esas fuentes cabe la posibilidad de sospechar que, más allá de ese uso, las haya utilizado porque el nombre le venía muy al dedillo como portador que era de otras connotaciones ocultas tras él.

Si con la elección del nombre Lázaro siguió el autor la corriente de una bien establecida tradición - y en qué sentido y hasta qué punto trataré de ello más adelante-, con la del sobrenombre Tormes ya ha visto también esa misma crítica general que debio inspirarse en otra de tanta o más solera y difusión, la de la mitología universal que quiere a tantos de sus héroes nacidos de las aguas; también aqui, no obstante, cabe sospechar algo más que la mera repetición de un mitema.

Parte de la crítica ya ha destacado que con el nacmiento fluvial atribuido a Lázaro el autor estaba apuntando a un immediato antecesor literario: Amadís de Gaula, por supuesto ${ }^{19}$. La presencia, otra vez, de Amadís, impone retomar el parangón antes iniciado, esta vez en la línea de los sobrenombres o apodos, para los cuales ha de hacerse notar una sugestiva diferencia de suficiente peso en esta cuestión; al Amadís que dice: "A mí llaman el Doncel del Mar" se opone su antónimo que dirá: "A mí llaman Lázaro de Tormes"; ambos aparecen, por tanto, dentro de un genérico plano de onomástica acuática, pero frente al extenso, indefinido y anónimo "Mar" del Doncel, se nos presenta el definido, concreto y perfectamente ubicable "Tomes" de Lázaro.

Así, en cuanto personaje literario Lázaro se distingue de Amadís por lo específico de este topónimo, pero, por otro lado, y mediante el uso del mismo topónimo, tázaro puede muy bien verse emparentado y comparado con otros personajes, pero ya no serán literarios como Amadís, sino, por el contrario, serán personajes en un plano real, el histórico; personajes como, pongo por ejemplo, Alonso de Cartagena, Pablo de Burgos, Alfonso de Baena, Antón de Montoro, Juan de Dueñas, Hernando de Talavera y aun el mismo, si bien menos conocido, Hernández de Móstoles que vimos antes.

Puede que fuera mero capricho por parte del autor la elección de un topónimo para su criatura cuando tan a mano tenía multitud de antropónimos - sin ir más lejos, le hubiera bastado dejarle con sus Gonzáles y Pérez, pero ya se vio por qué no lo hizo-, pero es más probable, en mi opinión, que deliberadamente estuviera siguiendo para su elección una tradición menor de aquellos tiempos, la fomentada y extendida entre los conversos de adoptar el lugar donde encontraron su nueva identidad oficial -entiéndase, su nuevo linaje mediante el bautismocomo sobrenombre, costumbre de la cual los históricos personajes citados arriba y elegidos a propósito como conversos que fueron, nos traen el recuerdo. Basta consultar listas inquisitoriales cualesquiera - como,

19 Cf. supra, nota 8; en especial, Asensio, p. 248. 
por ejemplo, la de Cantera Burgos citada antes en n. 16- o padrones como los publicados por Guillén o Bataillon para cerciorarse de lo común de esa práctica de bautismo toponímico entre cristianos nuevos, y buen epítome de lo regular que debía ser la tal práctica es la anécdota recogida por Gilman, en la que se nos informa que ". . .cuando un cierto Alonso de Ávila negó tener linaje converso. . . el librero Abraham García afirmó que "debía serlo o bien de baja condición, pues solo en estos ca" sos toman su apellido del lugar' ',20.

Parece, pues, que al igual que lo hicieron tantos de esos conversos, el autor ha querido para su Lázaro un determinado lugar como cuna de sus nuevos linajes, sobrenombre e identidad. Sobre la insistencia que pone en ello, y su porqué, haciendo decir a su mozo "Mi nacimiento fue dentro del rio Tormes" "con verdad me puedo decir nacido en el río" bastante ya he hablado antes y no es necesario detenerse más en ello, pero sí hay que hacerlo en otro detalle. Si tanto Lázaro como esos conversos históricos que he citado tienen un determinado lugar como origen de su nueva identidad, algo se da, no obstante, que los diferencia; frente al Burgos, al Montoro, al Talavera, al Móstoles, etc., de los segundos se alza el Tormes del primero, o, de otro modo, en oposición a ciudades concretas, un río de fluyentes aguas ${ }^{21}$.

Así como este autor no había querido un antropónimo para su personaje y le otorgó, por el contrario, un topónimo, asimismo, entre toda una serie de topónimos posibles, tampoco quiso concederle la gracia de una ciudad o pueblo para su nuevo origen; tuvo que ser un río cuando tan cómodamente pudo haber utilizado - y aun hubiera sido más lógico y consecuente- el Tejares de sus padres; no haciéndolo así, claro está que ratifica definitivamente el desgajamiento de Lázaro de su tronco familiar, pero como tampoco emplea los también muy lógicos y consecuentes Salamanca o Toledo de su vida, es obligado sospechar que algo más se oculta tras esa decisión de escogerle un río como lugar de origen ${ }^{22}$.

20 Stephen Gilman, La España de Fernando de Rojas, Taurus, Madrid, 1978, p. 132 nota 20; para los padrones, C. GULLLÉN, "Un padrón de conversos sevillanos", $B H i$, 65 (1963), 49-98 y M. BatallLon, 'Les nouveaux chrétiens de Ségovie en 1510 ", $B H i$, 58 (1956), 207-231. Costumbre ésta que no era exclusiva de los judeo-hispanos, aunque para otros las razones pudieran ser ligeramente distintas; hablando de los judíos expulsados de los estados papales, excepto Roma y Ancona en 1569, dice CECL RotH: "The majority of the exiles had no choice but to crowd together in the already congested Roman Ghetto. . To the present day the typical Roman Jewish surnames deriving from little provincial centers of the region -Tagliacozzo (di) Tivolo (di) Nola. . . testify to this fact" (cf. The history of the Jews in Italy, The Jewish Publ. Soc. of America, Philadelphia, 1946, p. 307).

21 Una sugestiva conclusión puede inferirse de la gradación de estos topónimos: en un extremo, Amadís, Doncel del Mar y personaje absolutamente literario; en el otro, un fray Hernando de Talavera o un Hernández de Móstoles, por ejemplo, reales figuras terrenas históricas; entre ellos, un Lázaro de Tormes, de un Tormes que como río participa tanto del mar como de la tierra y que con ello presenta una condición a caballo entre los literario y lo histórico.

22 Siquiera en nota hay que recordar que también sus grandes epígonos, Guzmán 
Para los conversos históricos, nueva identidad y bautismo venían a ser una misma y sola cosa, y a ella se adscribía de modo automático el nombre del lugar en donde tenía efecto la ceremonia y con ello, adquirido su nuevo nombre mediante el bautismo, venía a resultar que la mera mención de ese lugar evocaba, lógicamente, esos apellidos y esa ceremonia y retraía a ellos. Lo mismo es aplicable a Lázaro, pero para éste la referencia a la ceremonia se da por partida doble; en efecto, en su caso el lugar de su re-nacimiento es un río, y siendo así si la mención de Tormes como topónimo ya sugiere su bautismo; con ello converge la condición de ser ese topónimo precisamente un río que con lo característico de sus aguas - recuérdese el vehículo sacramental- sublima, así, el valor y trascendencia de ese bautismo.

Vuelvo a recordar cómo la insistencia de Lázaro en su nacimiento dentro del río era manifestación de la transmutación de las aguas amnióticas maternas en las fluviales del Tormes; avanzado el análisis se puede ampliar la interpretación, haciéndola más completa y transparente; unas primeras aguas amnióticas pasan a ser las fluviales del Tormes y éstas, a su vez, acabarán convirtiéndose en lo que realmente quiere el autor que sean: las aguas bautismales, causa y origen, en definitiva, del re-nacimiento de su criatura.

Por otra parte, ya se sabe que para el ingreso en una comunidad religiosa, sea ésta cual sea, es necesario un rito simbólico de iniciación; para Lázaro, y en concreto, si de un indeterminado ingreso e iniciación se tratara, es obvio que cualquier rito hubiera sido suficiente, pero no es éste el caso; el énfasis que el autor pone en escoger unas aguas como vehículo material de ese rito presupone una deliberada y subsiguiente obliteración de otro rito iniciático existente y vigente por aquellos años, y ni qué decir tiene que aludo a la circuncisión de la casta judía; el que menosprecie esta circuncisión y se decida por las aguas indica bien en qué particular comunidad religiosa hace ingresar a su protagonista y de rechazo qué otra, a la que debiera haber seguido perteneciendo de no darse ese bautismo, es abandonada y rechazada definitivamente.

De esas aguas surge, así, un hombre nuevo, un renacido que mediante el bautismo lustral borra el carisma de su anterior comunidad religiosa y se incorpora a otra muy específica: la cristiana; cumplidos esos requisitos nos hallamos con que este personaje se nos presenta, de ese modo, convertido en un cristiano nuevo más ${ }^{23}$.

Algo más había, pues, tras la elección del Tormes y sus aguas en

y Pablos, se verán necesitados de topónimos, pero, por el contrario, los de éstos serán citadinos - Alfarache y Segovia-, detalle contrastivo que en otra ocasión habré de examinar con más profundidad. Añádase, además, que ningún converso histórico llevó apellido fluvial, que yo sepa; lógico como es esto, el hecho de que el autor no haya seguido esa pauta realza lo simbólico de esa elección que paso a exponer en texto.

23 Lo que además tenga este cristiano nuevo del hombre nuevo que invita Erasmo a hacer nacer dentro de sí mismo al caballero de su Enchiridión, del hombre nuevo 
este autor cuando los tomó para lugar de re-nacimiento de su personaje y consecuente origen de su sobrenombre; habiéndolo de presentar como cristiano nuevo no tenía otra opción, pero su particular acierto consiste, en mi opinión, en que supo aprovecharse del topos mitológico, secular y prestigioso, que sus conocimientos clásicos le aportaron para adaptarlo, tamizado por su psicología de converso, a su especial propósito creador. Válido como pueda ser todo esto para el sobrenombre de Tormes, otro tanto creo que puede concluirse cuando el nombre Lázaro entra en consideración.

Suponiendo que el autor había decidido en principio utilizar fuentes evangélicas para su elección onomástica de Lázaro, a mano tenía las dos figuras de ese nombre: el Lázaro mendigo, hambriento y llagado de la parábola del rico avariento (Lucas: $16,19-31$ ) y el Lázaro de Betania resucitado por Jesucristo (Juan: 11, 1-44).

La mayor parte de la crítica se ha decidido por el primero como el escogido por el autor para epónimo de su personaje. Lo eligió, supone esa crítica, porque su intención era presentar un individuo mendigo, hambriento y desposeído, y evidentemente el Lázaro de Lucas era el más adecuado, dadas sus características, para prestarle nombre.

Lo curioso, sin embargo -y siento discrepar de la crítica-, es que este personaje no es tan mendigo ni tan hambriento ni tan desposeído como en una consideración superficial puede parecer. Hambres pasa, no hay lugar a dudas; pero ha de observarse en primer lugar que esas hambres solamente le afligen durante un primer período de su vida y no el más largo ni con mucho - baste traer aquí a colación los cuatro años, por lo menos, que pasa con el capellán y en los que el espectro de esas hambres se ha alejado totalmente-; por otra parte, cuando forzado por las mismas se dedica a la mendicidad, solamente lo hace, y de modo exclusivo, por un breve período durante su estancia con el escudero y en ningún momento mendiga, es casi innecesario recordarlo, mientras con el ciego y el clérigo se halla, y no digamos con los amos posteriores; se echa, además, de ver que los "tronchos de berza". el "pedazo de uña de vaca", etc., que pordiosea no son en ningún caso adquisiciones motivadas por el dañado impulso de vivir a costa del prójimo; por el contrario, al menos en parte, lo hace espoleado por la sana intención, muy piadosa y humana, de ayudar al prójimo, encarnado, como sabemos, en ese escudero que tenía "en el pobre Lázaro una cabeza de lobo" y a quien tenía que mantener, como tan tristemente nos confiesa. Y en fin, aunque desposeído y lastimado se pueda seguir sintiendo hasta salir del maestro de pintar panderos, hay que acordarse de sus días con el buldero donde no parece pasarlo demasiado mal y que ya con el capellán, como nos dice, sube "el primer escalón. . . para

mediante los caminos y/o experiencias iluministas o incluso nuevo como homo novus renacentista, es asunto en que no debo detenerme aquí, aunque sí corresponde dejar, al menos, constancia de él. 
venir a alcanzar buena vida"' (VI, pp. 6-7), lo que se ve certificado por esos ahorrillos y la ropa nueva que se merca.

No parece, pues, que ese muchacho sea una vera efigie del Lázaro mendigo y hambriento de Lucas ni que su vida, considerada en su totalidad, se ajuste punto por punto al mismo; se puede afirmar, pues, sin riesgo de exageración, que como representación de ese Lázaro de Lucas, el del autor resulta una figura excesivamente débil como para justificar por sí sola y de modo único la elección del nombre. Que para esa elección haya operado el epónimo evangélico, sí; que lo haya hecho de modo exclusivo, no tanto, y ya lo ha visto así cierta parte de la crítica como Deyermond, Gilman, Perry, Ferrán, para quienes si el Lázaro indigente de Lucas da nombre al mozo también - y quizás en mayor medidase lo da el resucitado de Juan².

Ocurre, en efecto, que si puede verse a ese Lázaro literario contigurado por sus hambres, mendicidad y laceria, no menos se le puede ver, aunque prima facie no resulte tan obvio, configurado asimismo por sus resurrecciones. Ya el resultado de la calabazada inicial se presenta como primera manifestación de cse rasgo; el "desperté de la simpleza que como niño dormido estaba" (I, pp. 97-98), ese surgir de un infantil sueño inocente para ingresar en la dolorosa realidad de los adultos no es dudoso que suscite inmediatamente la evocación de una simbólica resurrección; resurrección que se verá ratificada por lo que poco después dirá, hablando de quien le proporciona tan dolorido despertar, "éste me dio la vida y siendo ciego me alumbró. . ." (I, pp. 106-107), alumbramiento éste, a su vez, que, como sabemos, habrá de repetirsc a lo largo de su vida, y aun vida ésta que si se la da el ciego junto al alumbramiento y aunándose a él, no será la única vez, tampoco, que se la proporcionan, ya que también el vino le hará resucitar no una vez sino mil, como bien le amonesta el ciego: "A lo menos, Lázaro, eres más en cargo al vino que a tu padre, porque él una vez te engendró, mas el vino mil te ha dado la vida"' (I, pp. 361-363). Y también lo harán las mujercillas del tercer tratado, "a mí diéronme la vida unas mujercillas hilanderas. . ." (III, p. 366), indicios todos ellos de las frecuentes simbólicas resurrecciones que constituyen la personalidad de este mozo.

Donde esos indicios decisivamente dejan de serlo y convergen para epitomizar la condición de resurrecto será en la experiencia que Lázaro habrá de padecer bajo la férula del clérigo de Maqueda. Del resultado del fiero garrotazo que éste le atiza convencido de estar matando la culebra, dirá: "De lo que sucedió en aquellos tres días siguientes

24 Hace algunos años lo vio así A. D. Deyermond ("Lazarus and Lazarillo", Studies in Short Fiction, 2 (1965), 351-357, esp. p. 34, nota 13), rechazando muy acertadamente la categórica y gratuita afirmación de R. AlTER, art. cit. Asimismo GILMAn, art. cit.; C. GulLLín, ed., Lazarillo de Tormes and El Abencerraje, Dell, New York, 1966, pp. 27 y 28 de la introd.; T. A. Perry, "Biblical symbolism in the Lazarillo de Tormes", SPh, 67 (1970), 139-146; y J. FERRÁN, "Algunas constantes de la picaresca", $C I P(1), 54-55$. 
ninguna fe daré, porque los tuve en el vientre de la ballena'" (II, pp. 352-353).

Ya ha visto Guillén ${ }^{25}$ que ese episodio es eco y paráfrasis del texto evangélico de Mateo donde se lee: "Porque como estuvo Jonás en el vientre de la ballena tres días y tres noches así estará el Hijo del hombre, tres días y tres noches en el seno de la tierra' (12:40).

Esos tres días que Jesucristo profetiza son la premonición de los tres que él mismo habrá de estar en el sepulcro antes de resucitar; en boca de Lázaro "aquellos tres días siguientes"' son los que pasa sin sentido, como acto seguido nos informa: "A cabo de tres días yo torné en mi sentido. . ." (II, p. 356). La pasión y muerte de Cristo, que le llevarán ai sepulcro y a esos tres días de enterramiento tras los que resucitará, se remodelan paralelamente en el fiero garrotazo y en los tres, que Lá zaro pasará sin sentido, aparentemente muerto, y de los cuales tornará, simbólicamente reencarnado en la figura de Cristo resurrecto.

Estas experiencias, sin embargo, nos aparecen a su vez como una síntesis de otras que se habrán desarrollado a mayor escala; en el vientre de la ballena, como nuevo Jonás, ha permanecido Lázaro tres días, pero ese vientre y esos tres días resultan ser, cuando se les considera detenidamente, nada más que la forma encapsulada de un ámbito y un período mucho más extensos: la casa del clérigo y cuantos días Lázaro padece con él. En efecto, al comparar atentamente sus actividades en el segundo tratado con las de los restantes se echa muy bien de ver que es en éste cuando Lázaro se encuentra ex́ıcerrado a cal y canto en una casi absoluta reclusión; emparedado con su amenazante muerte, su rabiosa hambre, sus cebollas y su arcaz, prácticamente se halla sin contacto alguno con el exterior, y si ese aislamiento se rompe será de modo exclusivo bien para ayudar a misa - y esto bajo el inquisitivo e ineludible ojo del clérigo que "un ojo tenía en la gente y el otro en mis manos" (II, p. 55) - o bien, más trágica, irónica y significativamente para asistir a mortuorios ${ }^{26}$.

Hay que ver, pues, en todo el segundo tratado un evidente enterramiento en extenso, y las patéticas y obsesivas reflexiones que esmaltan su relato de ese período: "Vime claramente ir a la sepultura" (II, p. 47), "todo el tiempo que con el veví o, por decir mejor, morí" (II, pp. 5960 ), "viendo el Señor mi rabiosa y continua muerte"' (II, p 83), "en nada hallaba descanso, salvo en la muerte. . . que estaba siempre en mî" (II, pp. 88-91), nos dejan ver muy claro hasta qué punto Lázaro siente esa ominosa morada y ese fúnebre y alucinante período como la opresora sepultura y la lenta muerte que se ha visto obligado a padecer. Resulta una conclusión lógica afirmar que, cuando el clérigo "tórnase a meter en casa y cierra su puerta'” (II, p. 382), ese Lázaro expulsado,

25 Guillén, loc. cit.

26 En la p. 148 de mi trabajo (cf. supra, n. 12), hago ver otra consecuencia de esa reclusión: la psíquica. 
mejor diríamos vomitado del vientre de la ballena, es el perfecto resurrecto que sale a la luz de una nueva vida.

Gilman ya ha visto el proceso relacionado con el arcaz como ilustrativo de la simbólica muerte de Lázaro; no ha señalado, empero, esa condición de sepulcro de la morada y sí lo hace, en cambio, y muy en concreto, para la del siguiente amo, la del escudero que, para él, es "a sepulcher in which both master and man have been buried. . ."27 Sepulcro del que una vez más volverá a resucitar según opinión de Perry, para quien ". . . like the biblical Lazarus who returned to life on the fourth day, Lazarillo is resurrected. . . in the fourth tratado" 28 .

Resurrección tras resurrección, todas ellas se presentan, en fin, como epifanías de una intrínseca condición que se alberga en el fondo de la personalidad de este destrón: la de resurrecto. Así lo ve cierto sector de la crítica actual y así se vio también en su tiempo, en el que no era desconocida esta atribución y aun aparece reputada como la fundamental por algún lector de entonces, de no dudosas sensibilidad y cultura literarias.

Entre los sonetos satíricos y burlescos de Góngora, hay uno en que, representándose cegado por el amor, compara su situación con la relación ciego-Lázaro, y como nuevo Lázaro que ha despertado del engaño dirá de sí:

Fue mi resurrección la maravilla

Que de Lázaro fue la vuelta al mundo

De suerte que ia soi otro segundo

Lazarillo de Tormes en Castilla ${ }^{29}$.

Así entendió don Luis a ese personaje, como intrínseco resurrecto y en menoscabo del mendigo, y a buen seguro que no sería el único de entre los muchos lectores contemporáneos suyos ${ }^{30}$.

Conceder esa dimensión a su protagonista no debió de ser mero capricho del autor; admitidos los supuestos de que partió para la creación de su personaje, ese carácter básico de resurrecto era una condición es-

27 Gilman, art. cit., p. 165

28 PERry, art. cit., p. 146.

29 Luis de Góngora, Sonetos, ed. B. Ciplijauskikaité, Hispanic Seminary of the Medieval Studies, Madison, 1981; el soneto 104 se encuentra en la p. 329.

30 Quevedo, por ejemplo, dentro de su prolífica producción poética, cuatro veces recurre a ese personaje; una de ellas comienza: "Vivo y enterrado estuve / Lázaro fui de las fiestas. .. " (II, p. 213); otra dice: "Sobre quién las pegó a quien / ahí de podridos andan; / él, con humores, gabacho / y ella, Lázaro con llagas" (II, p. 296); una tercera: "Yo que lo pregono soy / el Lázaro miserable / que del sepulcro de viejas / quiso Dios resucitarme" (II, p. 368); y la cuarta: "El regalito de martas / que pide con tantas veras / como Lázaro su hermano / le enviaré de magdalenas" (II, p. 470). Cito por Francisco de Quevedo, Obra poética, 3 tomos, ed. J. M. Blecua (Castalia, Madrid, 1969, 1971). Sin que necesariamente Quevedo haya de estar pensando, como Góngora, en el Lazarillo, son sugestivas las tres referencias al Lázaro resucitado frente una sola al llagado y otra al mendigo. 
tructurante sine qua non, ya que el abandono de sus anteriores linaje, nombre e identidad a fin de conseguir los nuevos exigía, obviamente, el tránsito de una resurrección. Como un resurrecto lo concibió el autor, resurrecto de su vida anterior - la de su estirpe, la de sus Gonzáles y Pérez-y en consecuencia Lázaro le hubo de nombrar, aunque habría que decir mejor que Lázaro hizo que le nombraran los otros, como así es en efecto.

Se comprueba en el texto que el nombre no aparece en momento alguno durante el tiempo que este mozo pasa bajo la tutela materna, cuando todavía vive con los de su linaje; dada la exclusiva, o casi exclusiva, presentación en estilo indirecto de estos primeros pasajes parece comprensible que así sea, pero que cuando su madre le despide lo haga diciéndole simplemente: "Hijo, ya sé que no te veré más" (I, p. 82) y no "Lázaro, hijo mío. . ." o "Lázaro, hijo. . .", por ejemplo, deja suponer que esa omisión sea una más deliberadamente propuesta.

Lo cierto es que sólo en boca del ciego aparece por primera vez ese nombre, "Lázaro, llega el oído a este toro. . ." (I, p. 89), y subsiguientemente en las de sus otros amos, y así ha de ser si el autor actúa de acuerdo con los supuestos que le vengo atribuyendo, ya que únicamente para éstos, como representantes que son de esa nueva comunidad en que ingresa Lázaro, éste ha de presentárseles como resurrecto y no, por supuesto, para los de su linaje que difícilmente le podían ver como tal; de ahí que sean esos mismos quienes hayan de adjudicarle primero el nombre de Lázaro para acabar su labor imponiéndole el de Tormes que coronará el simbólico proceso; o lo que es decir, la resurrección dará paso - ya autenticada por el nombre Lázaro- a un proceso de indoctrinación del neófito, su peripecia vital-, y superado éste al ingreso definitivo en la comunidad con el bautismo final, confirmado por el de Tormes.

Así, ser Lázaro y ser de Tormes presupone y significa simbólicamente haber sido resurrecto y bautizado, haberse constituido en cristiano nuevo, encerrando su nombre total, de ese modo, tanto la esencia de su última identidad cuanto la confesión del proceso a través del cual le ha sido concedida.

Algo más queda por decir de ese nombre. La gran parte de la crítica que no ha reparado en la motivación que propongo para la elección del Lázaro resucitado de Juan como epónimo sigue, sin embargo, teniendo razón en preferir al Lázaro de Lucas, y la tiene, aunque involuntariamente, por otro detalle que caracteriza a ese último Lázaro evangélico.

Se lee en Lucas (16: 20-21): "Un pobre, de nombre Lázaro, estaba echado en su portal, cubierto de úlceras, y deseaba hartarse de lo que caía de la mesa del rico; hasta los perros venían a lamerle las úlceras".

Hambriento y mendigo nos lo presenta Lucas, pero también, y quizás no menos, ulcerado. ¿Hasta qué punto contó esta característica en el autor cuando se decidió por el nombre, supuesto que la tuviera en cuenta?

Américo Castro lo da por descontado: “. . . el autor lo llamó así por 
ser Lázaro - el pobre leproso mencionado en los Evangelios- un prototipo para cualquier existencia miserable y doliente".

Otros dos conocidos críticos la suponen; Bataillon afirma: "El nombre debía su resonancia lastimosa a su conexión con el infortunio de San Lázaro, patrón de los leprosos y de sus leproserías y lazaretos", y para Márquez Villanueva ". . . el nombre de Lázaro. . . alcanza plena intención. . . por reencarnar al mendigo evangélico, el identificado por el pueblo con la laceria, las llagas y la gafedad. . "'31

Esos tres juicios, además de suponer una afirmativa, nos informan de las dos conocidas fuentes, la bíblica y la histórica medieval, que conclusivamente asociaron la condición de leproso al nombre Lázaro. Aceptados los mismos, sospecho, no obstante, que hay alguna otra razón más recóndita para la elección del autor.

Habrá que acudir a textos históricos que nos puedan proporcionar alguna pista en esta línea. Lucio Marineo Sículo, en De las cosas memora bles de España, explica el porqué del rechazo de los antiguos hebreos respecto a los extranjeros:

. . .porque como fuessen fatigados grauemente de sarna y roña echaron a Moysses con sus enfermos de los términos de Egipto, porque aquel mal no se apeggase a otros. Así que Moysses capitán de los desterrados. . . porque tenía memoria que los auían echado de Egipto porque no se les pegasse su indisposición y porque en quien habitassen no ios aborresciessen quissieron proueer de no comunicar con estranjeros ${ }^{32}$.

Lo que acumule de aviesa leyenda, distorsionada tradición o real historia, o mezcla de todo, Marineo Sículo es cuestión a discutir; lo que no parece discutible es la generalizada creencia, por la primera mitad del Xvi, al menos - conocidas las posteriores ediciones de su De Hispanis laudibus de hacia 1497, yo cito por la de 1539-, de que los hebreos padecían ya desde sus orígenes un tipo de congénita sarna o roña, léase lepra, y aun de que esa misma y no su condición de pueblo elegido les obligaba a separarse de otras gentes.

Que a lo largo de la Alta y Baja Edad Media los hebreos eran vistos como portadores de peste y lepra, que el pueblo común, en general, les atribuía supersticiosa e indiscriminadamente el origen de pestes y epidemias, y que, además, como comunidades marginadas en sus juderías fácilmente se les confundía con leprosos, está suficientemente documen$\operatorname{tado}^{33}$ y no hay por qué detenerse en ello. Sí, en cambio, en el particu-

31 Américo Castro, 'Hacia Cervantes, Taurus, Madrid, 1957, p. 145; Batalllon, op. cit., p. 27; y F. MÁrquez Villanueva, op. cit., p. 110. Para la paleontología lingüística de Lázaro, sus diversos significados y la relación Lázaro-leproso, cf. Y. MALkiel, "La familia léxica lazerar, laz(d)rar, lazeria", NRFH, 6 (1952), 210-276.

32 Lib. XIX, f. clxiii v. de la ed. de 1539

33 Por los años 1320 y 1321, por ejemplo, se dieron en Francia abundantes quemas colectivas de judíos y leprosos que se confundían indiscriminadamente (cf. YiTzHAK 
lar cariz que la cuestión tomó desde finales del xv a raíz de la expulsión y la correspondiente conversión masiva.

Bernáldez, hablando de la herética pravedad y de las abundantes quemas que se produjeron entre judaizantes, aconseja: ". . .que pues el fuego está encendido / será necesario arder hasta que sean desgastados y muertos todos los que judaizaron, que no quede ninguno; y aun sus hijos. . . que fueron tocados de la misma lepra"'34.

La lepra hebraica original se ha ido transformando insidiosamente en algo distinto, ha abandonado su carácter de mal puramente somático para sublimarse en una dolencia cargada de contenido ideológico; parece ya que para esos años ser converso es ser leproso, indiscriminadamente, sin atender a la individual salud fisica de cada uno; tener sangre judía era ser leproso, pero con la particularidad de que esa lepra había dejado de ser considerada como pura infección somática, para dar paso a un morbo con toda la carga ideológica del antisemitismo.

$Y$ en este singular elemento, la sangre, se centrará la polémica que, iniciada muchos años atrás con la Sentencia-Estatuto de Pedro Sarmiento en 1449, había seguido candente durante el resto del xv y se fue endureciendo más y más, tras la expulsión y conversión, hasta acabar con los provocativos y famosos Estatutos de limpieza de sangre del arzobispo Silíceo en 1547. A no dudar que en el intervalo - especialmente la primera mitad del XVI- muchas de las pasiones, represalias y odios que entonces se fomentaron hubieron de entretejerse alrededor de esa cuestión de la "sangre infecta" o "impura" como condición fisiológica inherente a la casta conversa y de la cual les era imposible deshacerse;

BAER, A history of the Jews in Christian Spain, The Jewish Publ. Soc. of America, Philadelphia, 1966, t. 2, p. 9), debido, entre otras cosas, a los rumores que circularon de que los judíos estaban envenenando las aguas y contagiando la lepra como ya señala Luis SuÁrez Fernández (Judíos españoles en la Edad Media, Rialp, Madrid, 1980, p. 167), donde añade que la calumnia también pasó a España; véase también VICENTE Risco (Historia de los judíos desde la destrucción del templo, Ed. Gloria, Barcelona, 1944, p. 259) para leyendas sobre el compadrazgo de leprosos y judíos y la atribución supersticiosa a éstos de pestes y epidemias; y, para la atribución de lepra a comunidades marginadas, Juan G. Atienza, La meta secreta de los templarios, Martínez Roca, Barcelona, 1979 , pp. 243 y 257.

34 Andrés Bernáldez, Historia de los Reyes Católicos, en Crónicas de los Reyes de Castilla, $B A E, 70$, pp. $601 b-602 a$. Esa lepra, por supuesto, y dada la inquina y resabios de los cristianos viejos o de quienes de ello presumían, no se limitaba a los judíos; la otra supuesta herejía, la mora, lo era también; comentando la toma del reino de Granada, Garci Rodríguez de Montalvo en Las Sergas de Esplandián hablará de los Reyes Católicos como de quienes "limpiaron (el país) de aquella sucia lepra; de aquella malvada herejía que en sus reinos sembrada por muchos años estaba. . ." (cfi $B A E, 40$, p. $505 b$ ); Bartolomé Gutiérrez, Año Xericiense: Diario eclesiástico y civil de la mui noble y mui leal Ciudad de Xerez de la Frontera (Xerez, 1755), informa que el 9 de agosto de 1494 "se pregonó en Xerez con graves penas, no se diesse acogida a un gran número de Christianos nuevos, que havian antes desembarcado en el Puerto de Sancta Maria, por ser nuevos Christianos y venir de partes infectas de peste" (p. 60), peste que es muy dudoso que fuera de simple carácter somático. 
y como consecuente prueba de la intensidad con que esto se debió producir ahí están los posteriores tratados, comenzados con el de Juan Arce de Otálora y seguidos por los de Pelaes de Meres, Villar Maldonado y otros, que teorizando sobre el asunto acabaron acuñando definitivamente ese concepto.

Sangre infecta, lepra, castigo e ignominia por su deicidio, contaminaba a toda la casta y se transmitía ineludiblemente mediante todas y cada una de las secreciones - leche materna, semen, etc.-, llegando a adquirir indeleble carácter genético como ya ha expuesto Henri Méchoulan en su estudio, al que hay que acudir tanto como al trabajo de A. Sicroff cuando de toda esta cuestión se trata ${ }^{35}$.

Como el nombre de Lázaro con su específica carga connotativa encierra en sí el estigma de esa lepra, no es extraño que el autor - muy al día, sin duda, de esas contiendas sobre la "sangre infecta" y sus consecuencias - viera en el mismo otra adecuada oportunidad para su uso añadiendo con él para su personaje, además de la anterior condición de resurrecto, ésta de simbólico cirineo que, cargando con la secular culpa hebraica, la representa. Leproso, resurrecto, hambriento, mendigo y lacerado, el personaje sólo pudo llamarse Lázaro.

Del mismo modo que para la elección del sobrenombre el autor supo valerse del topos que le facilitó la mitología clásica, igualmente de otra tradición, la hagiografía evangélica, supo aprovecharse para el nombre. Buen conocedor de sus clásicos y no peor letrado, como buen descendiente de conversos que hubo de ser en la línea de un Hernando del Pulgar, un Fernando de Rojas, un fray Luis de León, un Arias Montano, bien supo este autor, partiendo de su peculiar psicología, sacar provecho del acervo tradicional para sus propósitos creadores.

Converso como debió ser, repito - y no soy el único, por supuesto, que le supone esa condición ${ }^{36}$-, no nos debemos llamar a engaño por el diferente énfasis que adscribe a los varios rasgos que caracterizan a su personaje. Ya hace algunos años que I. S. Révah llamó la atención al hecho de que la literatura de conversos o descendientes de ellos es una literatura de disimulación ${ }^{37}$, y las ironías, sutilezas y ambigüedades que recorren el Lazarillo algo dicen de eso, y entre ellas no debe ser

35 Henri Méchoulan, Le sang de l'autre ou l'honneur de Dieu: indiens, juifs, morisques dans l'Espagne du Siècle d'Or, Fayard, Paris, 1979, esp. cap. 2; Albert A. Sicroff, Les controverses des status de "pureté de sanq" en Espagne du xv $v^{e}$ au xvite siècle, Didier, Paris, 1960 , esp. cap. 7.

36 A. D. Deyermond (Lazarillo de Tormes: A critical guide, Grant \& Cutler-Tamesis Books, London, 1975, pp. 26-27) enumera a los autores que mantienen esta tesis; pueden añadirse, por ejemplo D. E. BEST, "Para la etimología de pícaro", NRFH, 17 (1963-64), 352-357; F. Márquez Villanueva, "Un aspect de la littérature du 'fou' en Espagne", en A. Redondo et al, eds., L'humanisme dans les lettres espagnoles. XIX ${ }^{\mathrm{e}}$ Colloque International d'études humanistes (Tours, 5-17 juillet 1976), Librairie Philosophique J. Vrin, Paris, 1979, 246-247; y H. MANCING, "El pesimismo radical del Lazarillo de Tormes", CIP(1), p. 466.

37 I. S. RÉvah, "Les Marranes", REJ, 1(1959-60), p. 71. 
la menor que nos presente a ese Lázaro enmascarado tras el biombo de sus hambres y lacerias para disimular mejor, con un malicioso guiño, su verdadera condición de leproso y resurrecto, sustratos básicos para acabar en cristiano nuevo, que si para nosotros, lectores del siglo veinte -y alejados, por tanto, de la atmósfera y tensiones del XVI-, pueden pasar inadvertidos, es dudoso que no fueran reconocidos por sus contemporáneos, metidos de lleno como estaban en esa situación histórica.

Borges, en uno de sus más inimitables poemas, El Golem, empieza:

\author{
Si (como el griego afirma en el Cratilo) \\ El nombre es arquetipo de la cosa, \\ En las letras de rosa está la rosa \\ $Y$ todo el Nilo en la palabra Nilo.
}

Puede que también esto sea aplicable a Lázaro de Tormes y que, ciertamente, toda su índole de leproso, resurrecto, hambriento y mendigo esté encapsulada, como vengo sugiriendo, en ese su nombre. De ser así, podría darse que la obsesión hebraica de ese Judá León, rabino de Praga, que empedernido cabalista "se dio a permutaciones / de letras y complejas variaciones" para acabar creando el Golem de la leyenda y del poema borgiano, plasmando así en simbólica criatura la justificación de los sufrimientos del pueblo judío en espera de su Mesías, fuera también, acaso, la misma que infundió ánimos y alentó al anónimo autor que forjó su personal Golem, Lázaro de Tormes.

\title{
Manuel. Ferrer-Ghivite
}

University College, Dublin. 